\title{
Development and characterization of cerium oxide catalyst supported on ceramic honeycomb substrate to reduce emissions of spark ignition engine
}

\author{
M. C. Math ${ }^{1 *}$ and M.S. Manjunath ${ }^{2}$ \\ ${ }^{1}$ Department of Thermal Power Engineering, Visvesvaraya Technological \\ University Post Graduation Center, Mysuru, Karnataka (India) \\ *mcmath1018@yahoo.com \\ +919916139979 \\ ${ }^{2}$ Department of Thermal Power Engineering, Visvesvaraya Technological \\ University Post Graduation Center, Mysuru, Karnataka (India)
}

\begin{abstract}
ABTRACT
This paper presents an innovative method to reduce cold start emissions of a four-stroke three-cylinder multi point fuel injection spark ignition engine. In this work, a glow plug is used as a heating source to maintain the activation temperature of a catalytic converter. This method is less complex than variable vacuum insulation method. In this work, cerium oxide $\left(\mathrm{CeO}_{2}\right)$ coated on the ceramic honeycomb substrate was used as a catalyst to lower the cost of a catalytic converter. A reduction of $34 \%$ carbon monoxide and $33 \%$ un-burnt hydrocarbon was observed at the idling condition with $\mathrm{CeO}_{2}$ as the catalyst and glow plug as the heating source in the catalytic converter. The results obtained from the engine which is fitted with $\mathrm{CeO}_{2}$ coated catalytic converter show the lowest emissions at all loads. Carbon monoxide and un-burnt hydrocarbon emissions (with catalytic converter) have reduced $68 \%$ and $71 \%$, respectively, in comparison with a non-catalytic converter engine test at full load engine operation. The new catalytic converter competes with the existing noble metal-based catalytic converter due to the use of inexpensive $\mathrm{CeO}_{2}$ as a catalyst.
\end{abstract}

Keywords: Catalytic Converter, Cerium Oxide $\left(\mathrm{CeO}_{2}\right)$, Ceramic material, Glow plug.

\section{INTRODUCTION}

Catalytic converter converts more harmful gases like carbon monoxide (CO), un-burnt hydrocarbon $(\mathrm{HC})$, and oxides of nitrogen $\left(\mathrm{NO}_{\mathrm{x}}\right)$ into less harmful gases like carbon dioxide $\left(\mathrm{CO}_{2}\right)$, water vapour $\left(\mathrm{H}_{2} \mathrm{O}\right)$, and molecular nitrogen $\left(\mathrm{N}_{2}\right)$. In an internal combustion (IC) engine, the time required for the complete combustion and other processes is much less at a higher engine speed which causes the incomplete combustion of the fuel [1-3]. This leads to the formation of the $\mathrm{HC}, \mathrm{NO}_{\mathrm{x}}\left(\mathrm{NO}\right.$ and $\left.\mathrm{NO}_{2}\right)$, and $\mathrm{CO}$ inside the engine cylinder. These emissions are particularly high during the idling and deceleration [1]. Carbon monoxide is a product of partial combustion of hydrocarbon in fuel. It is always present when there is a lack of oxygen during the combustion and thus, directly dependent on the applied engine air/fuel ratio [1]. There are several paths that cause hydrocarbons in the exhaust. The most obvious is, as to the cause of $\mathrm{CO}$, a lack of oxygen when the air/fuel mixture is rich $[1,4] . \mathrm{NO}_{\mathrm{x}}$ is formed during combustion in the engine when oxygen reacts with nitrogen at an elevated combustion temperature [5-11]. Methods like after burner, exhaust manifold reactor, catalytic converter, and exhaust gas 
recirculation are used to treat the automotive exhaust gases $[5,12]$. This paper focuses on catalytic converter technology.

In a conventional catalytic converter, materials such as platinum, rhodium, gold, etc. are conventionally used as catalysts which are highly chemically reactive with the exhaust gas emissions at high temperature [1]. Generally, two types of catalyst materials are used: a reduction catalyst and an oxidation catalyst usually made of noble materials $[1,13]$. The reduction catalyst uses platinum and rhodium to reduce the $\mathrm{NO}_{\mathrm{x}}$ emissions. When $\mathrm{NO}$ or $\mathrm{NO}_{2}$ molecule contacts the catalyst, the catalyst rips the nitrogen atom out of the molecule and holds on to it, freeing the oxygen in the form of $\mathrm{O}_{2}$. The nitrogen atoms bond with other nitrogen atoms and stuck to the catalyst, forming $\mathrm{N}_{2}$ [14]. The oxidation catalyst is the second stage of the catalytic converter. It reduces the unburned hydrocarbons and carbon monoxide by burning them over a platinum and palladium catalyst. This catalyst aids the reaction of the $\mathrm{CO}$ and hydrocarbons with the remaining oxygen in the exhaust gas [15]. Figure 1 shows the catalytic converter chemical process.

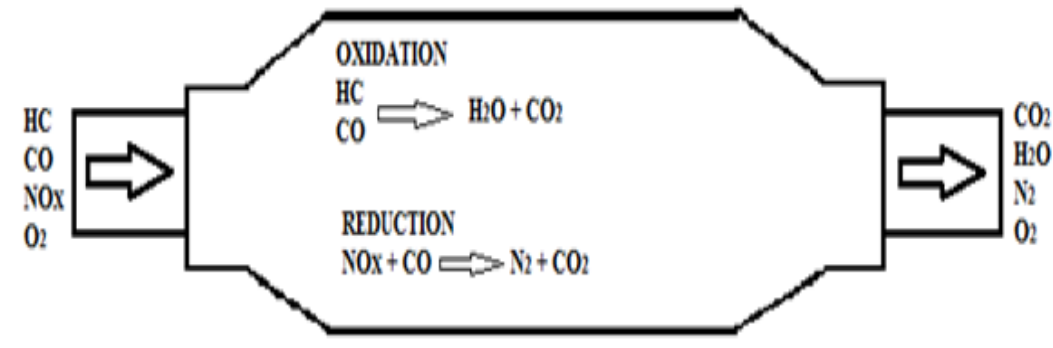

Figure1. Catalytic converter chemical process [16].

Ceramic honeycomb and beads are the two types of substrates used in the catalytic converter [17]. Most cars today use honeycomb structure. The present catalytic converters use noble metals as catalysts which are rarely available in earth crust and they are exhausted one day. The cost of extraction of noble material from the earth's crust is high and hence, causes an overall increase in the cost of the catalytic converter. In addition to this, the activation temperature of the catalytic converter made of noble material is higher than the non-noble materials [18]. Considerable work has been done to use non-noble metals as catalysts [19]. One of the researchers has developed a wire mesh, copper catalytic converter for a volume of $1.54 \mathrm{~m}^{3}$ [20] and the experiment was carried out on a four-stroke single cylinder compression ignition (CI) engine. It is found that the $\mathrm{HC}$ is reduced by $38 \%$ and $\mathrm{CO}$ by $33 \%$ at full load. Efforts have been made to develop a cost effective catalytic converter (CAT) for diesel engines by using catalyst materials consisting of a combination of metal catalyst such Cerium Oxide $\left(\mathrm{CeO}_{2}\right)$, zirconium dioxide $\left(\mathrm{ZrO}_{2}\right)$, silver nitrate $\left(\mathrm{AgNO}_{3}\right)$, and copper nitrate $\left(\mathrm{Cu}\left(\mathrm{NO}_{3}\right)_{2}\right)$ on pellets substrate [21]. These catalyst materials are inexpensive than conventional catalysts (noble metals) such as palladium or platinum. It is reported that the catalyst combination $\left(\mathrm{Cu} / \mathrm{CeO}_{2} / \mathrm{ZrO}_{2}+\left(\mathrm{Ag} / \mathrm{CeO}_{2} / \mathrm{ZrO}_{2}\right)\right.$ gives maximum back pressure (78 to 290 mbar) and the three major pollutants $\mathrm{HC}, \mathrm{CO}$, and $\mathrm{NOx}$ have been reduced with emission conversion efficiency of $62.29 \%, 64 \%$, and $59.7 \%$, respectively [21]. It is also reported that the catalyst combination $\left(\mathrm{Cu} / \mathrm{Ag} / \mathrm{CeO}_{2} / \mathrm{ZrO}_{2}\right)$ gives minimum back pressure (46 - 148 mbar) and the three major pollutants $\mathrm{HC}, \mathrm{CO}$, and NOx have been reduced with emission conversion efficiency of $61.1 \%, 62 \%$, and $64.3 \%$, respectively [21]. Efforts have been made to study the performance and emission characteristics of a four-stroke multi cylinder spark ignition engine with a Multi Point Fuel Injection (MPFI) system operating with 
Oxyrich air energizer [22]. It is concluded that a complete combustion can be obtained by increasing the oxygen quantity in air intake with a magnetic effect on the air. It is reported that $10 \%$ to $25 \%$ efficiency has increased and the specific fuel consumption has decreased (saving fuel up to 15\%). The main pollutants of petrol engine ( $\mathrm{CO}$ and $\mathrm{HC}$ ) are also decreased. In this method, both pollutants are reduced up to $20 \%$ to $30 \%$. The other pollutants of petrol engine which are $\mathrm{CO}_{2}, \mathrm{O}_{2}$, and $\mathrm{N}_{2}$ have increased with the increase in load and oxygen blend quantity [22]. The effectiveness of a catalytic converter mainly depends on operating temperature and gas feed composition. The optimum operating temperature for catalytic converters is around $200^{\circ} \mathrm{C}$ to $300^{\circ} \mathrm{C}$ [23]. It takes a few minutes for the engine to warm up. During this warm up period, at least $60 \%$ to $80 \%$ of toxic emissions occur [24]. The toxic emissions that escaped unfiltered during warm up period of the engine are called cold start emissions.

Many approaches have been proposed to reduce the cold start emissions [24-26]. The electrically quick heating method was also tried to reduce cold start emissions. This method requires an energy input of about $2 \mathrm{~kW}$ and 30 seconds to produce the operating temperature. However, this method does not eliminate cold emissions completely, it only reduces the cold start emissions level [24]. The cold start emissions can also be reduced by fitting the catalytic converter closer to the engine. It helps the converter to reach its operating temperature quickly. However, there is a danger of overheating of the converter [24]. A combination of vacuum insulation and phase change material helps to eliminate cold start emissions. Vacuum insulation prevents the transfer of radiant heat from the exhaust to the surroundings, preserving heat between the trips. Phase change material acts as a heat storage system and releases heat to the converter during cold start condition [24]. One of the researchers has made an attempt to improve the effectiveness of catalytic converters via reduction of cold start emissions [25-27]. This work involves the use of variable thermal conductance to improve the amount of heat that can reach the converter. Low conductivity helps to retain heat between trips, but high conductivity helps to reject excess heat while the catalytic converter is running. Vacuum insulation provides a practical solution to these requirements [26].

The main objective of this research is to develop a cost effective non-noble metal based catalytic converter to be used with a spark ignition engine. Hence, in this research, an attempt has been made to use $\mathrm{CeO}_{2}$ as a catalyst material in a catalytic converter because of its lower cost and lesser activation temperature than the noble materials. In this research, an attempt has also been made to reduce the cold start emissions by using a glow plug as the heating element.

\section{MATERIALS AND METHODS}

Table 1 shows the materials used for the fabrication of a catalytic converter. The outer casing is made of stainless steel in order to provide structural strength. The honeycomb structure is the main structural component of a catalytic converter. Ceramic honeycomb is selected because it has a good thermal stability, high catalytic activity, high strength, and long life. Ceramic honeycomb structures offer maximum surface areas with minimal volume. Figure 2 shows the Ceramic Honeycomb Monolith Substrate. In this work, two ceramic honeycomb structures are used as substrates. One is a simple ceramic honeycomb structure and the other is a ceramic honeycomb structure coated with $\mathrm{CeO}_{2}$. Non-coated and $\mathrm{CeO}_{2}$ (catalyst) coated ceramic cylindrical shape honeycomb substrates were imported from the Nanjing Depurate Catalyst Co., Ltd Nanjing, China. The cylindrical honeycomb structure has $100 \mathrm{~mm}$ diameter and $100 \mathrm{~mm}$ length. Figure 3 shows a non- 
coated and $\mathrm{CeO}_{2}$ coated ceramic honeycomb substrate materials. The cylindrical honeycomb structure has a weight to volume ratio of $0.40\left(\mathrm{~g} / \mathrm{cm}^{3}\right)$ with a cell density of $62\left(\right.$ cells $\left./ \mathrm{cm}^{2}\right)$. The substrate has a length of $100 \mathrm{~mm}$ and diameter of $100 \mathrm{~mm}$. The substrate has a low pressure drop, chemical inertness, and structural stability at temperature up to $500^{\circ} \mathrm{C}$. In this work, cerium oxide is used as a catalyst to promote oxygen storage, which in turn improves oxidation stability. Cerium absorbs excess oxygen and releases it under low oxygen conditions which improve the oxidation efficiency of $\mathrm{HC}$ and $\mathrm{CO}$ [24]. In addition to this, Cerium Oxide is inexpensive than noble metals.

Table 1. Materials used for the fabrication of catalytic converter.

\begin{tabular}{llll}
\hline S1. No & Part Name & Material & Reasons \\
\hline 01 & $\begin{array}{l}\text { Outer } \\
\text { casing }\end{array}$ & Stainless steel & $\begin{array}{l}\text { Longer life, durability, } \\
\text { minimum expansion, } \\
\text { deformation }\end{array}$ \\
02 & $\begin{array}{l}\text { Monolith } \\
\text { Substrate }\end{array}$ & $\begin{array}{l}\text { Ceramic (honeycomb shape) } \\
\text { mixed with precious metals and } \\
\text { wash coat has been formulated } \\
\text { for the storage of oxygen }\end{array}$ & $\begin{array}{l}\text { Good thermal stability, } \\
\text { high catalytic activity, } \\
\text { high strength, long life. }\end{array}$ \\
03 & $\begin{array}{l}\text { Glow Plug } \\
\text { Cerium } \\
\text { Oxide }\end{array}$ & & $\begin{array}{l}\text { Heating element } \\
\text { Catalyst }\end{array}$ \\
\hline
\end{tabular}
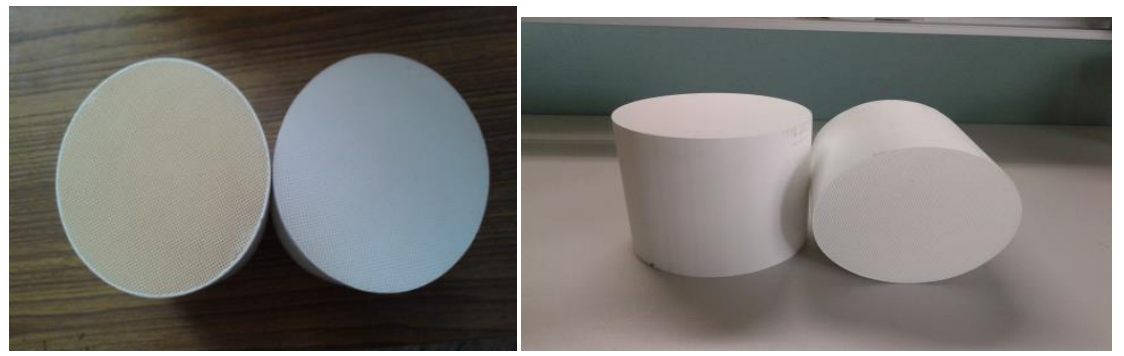

Figure 2. Ceramic honeycomb monolith substrate.

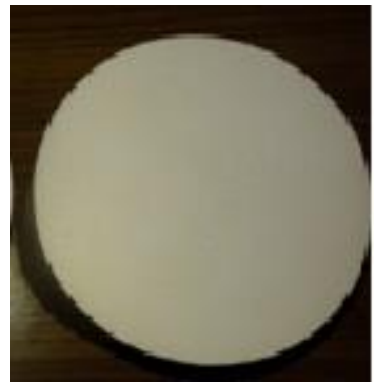

(a) Non coated

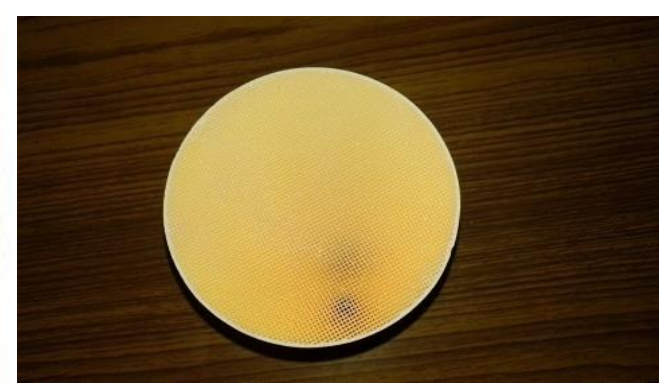

(b) $\mathrm{CeO}_{2}$ Coated

Figure 3. Ceramic honeycomb substrate.

Table 2 describes the product test report of the ceramic honeycomb substrate (noncoated type and catalyst coated type) which were obtained from the Nanjing Depurate 
Catalyst Co., Ltd Nanjing, China. Table 3 describes the product test report of the coating material.

Table 2. Product test record of ceramic honeycomb substrate (non coated and coated).

\begin{tabular}{|c|c|c|c|}
\hline Item Name & Standards & $\begin{array}{l}\text { Test result } \\
\text { (Non coated) }\end{array}$ & $\begin{array}{l}\text { Test result } \\
\left(\mathrm{CeO}_{2} \text { coated }\right)\end{array}$ \\
\hline $\mathrm{SiO}_{2}(\%)$ & $49.7 \pm 1.5$ & 50.35 & 50.35 \\
\hline $\mathrm{Al}_{2} \mathrm{O}_{3}(\%)$ & $35.4 \pm 1.5$ & 35.80 & 34.54 \\
\hline $\operatorname{MgO}(\%)$ & $13.5 \pm 1.5$ & 13.10 & 13.9 \\
\hline Cell Density $\left(\right.$ cell $\left./ \mathrm{cm}^{2}\right)$ & $62 \pm 3$ & 62 & 62 \\
\hline Wall Thickness (mm) & $0.18 \pm 0.02$ & 0.17 & 0.17 \\
\hline Volume Weight $\left(\mathrm{g} / \mathrm{cm}^{3}\right)$ & $\leq 0.55$ & 0.40 & 0.42 \\
\hline Moisture Absorption (\%) & $25 \pm 5$ & 25.9 & 26.1 \\
\hline $\begin{array}{l}\text { Thermal Expansion Coefficient } \\
\left(* 10^{-6} /{ }^{0} \mathrm{C}\right)\end{array}$ & $\leq 1.8$ & 1.27 & 1.30 \\
\hline $\begin{array}{l}\text { Thermal Shock Resistance } \\
\text { (Air cooled) }\end{array}$ & $\begin{array}{l}\text { No cracking as } \\
\text { putting in } \\
\text { temperature of } \\
500^{\circ} \mathrm{C} \text { than } \\
\text { take out to } \\
\text { nature cooling } \\
\text { for three times }\end{array}$ & $\begin{array}{l}\text { No cracking as } \\
\text { putting in } \\
\text { temperature of } \\
500^{\circ} \mathrm{C} \text { than } \\
\text { take out to } \\
\text { nature cooling } \\
\text { for three times }\end{array}$ & $\begin{array}{l}\text { No cracking as } \\
\text { putting in } \\
\text { temperature of } \\
500^{\circ} \mathrm{C} \text { than } \\
\text { take out to } \\
\text { nature cooling } \\
\text { for three times }\end{array}$ \\
\hline
\end{tabular}

Table 3. Product test record of coating material.

\begin{tabular}{lll}
\hline Item Name & Standards & Test result \\
\hline $\mathrm{Zr}$ (Hf)O & $24 \pm 1$ & 24.07 \\
$\mathrm{CeO}_{2}$ & $68 \pm 1$ & 67.94 \\
$\mathrm{La}_{2} \mathrm{O}_{3}$ & $8 \pm 1$ & 7.99 \\
$\mathrm{Na}_{2} \mathrm{O}$ & $<0.01$ & $<0.01$ \\
$\mathrm{SiO}_{2}$ & $<0.05$ & $<0.05$ \\
$\mathrm{Fe}_{2} \mathrm{O}_{3}$ & $<0.01$ & $<0.01$ \\
$\mathrm{SO}_{4}{ }^{-2}$ & $<0.03$ & $<0.03$ \\
\hline
\end{tabular}

The Catalytic converter is made cylindrical because it is easy to fabricate and easy to maintain. It requires minimum assembly time and it is rigid. Catalyst volume $\left(1570796.23 \mathrm{~mm}^{3}\right)$ and space / residence time / holding time $(10135.26 / \mathrm{hr})$ were calculated using the standard formulae. The fabrication of Figure 4 shows the details of parts of the catalytic converter. Figure 5 shows the assembled catalytic converter. The outer casing has a diameter of $104 \mathrm{~mm}$ and length of $350 \mathrm{~mm}$. The casing contains a $100 \mathrm{~mm}$ diameter and $100 \mathrm{~mm}$ length two honeycomb ceramic substrates which are surrounded by a $2 \mathrm{~mm}$ thick stainless steel mesh to hold the material tightly. The inlet cone length of the casing is $200 \mathrm{~mm}$ and outlet cone is $100 \mathrm{~mm}$. The inlet cone length is kept larger than the outlet cone length in order to reduce the thermal stress. 


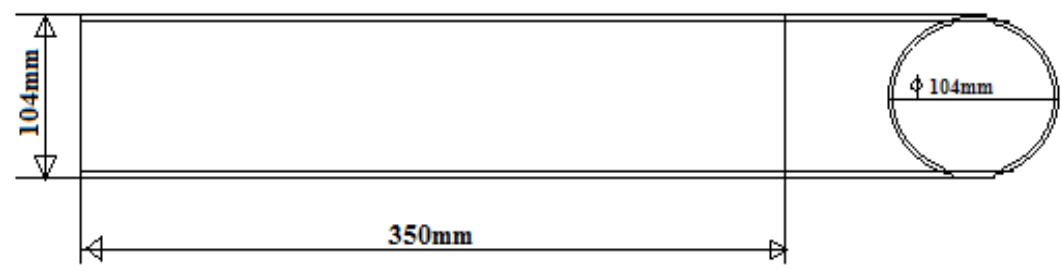

(a) Catalytic Converter Casing

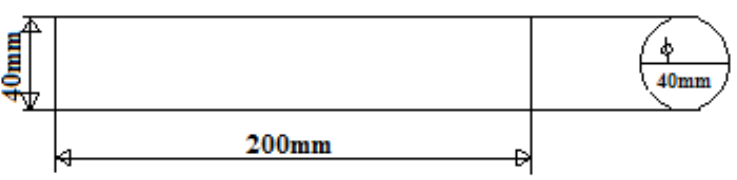

(b) Inlet Cone

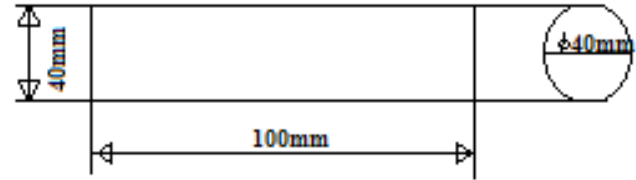

(c) Outlet Cone

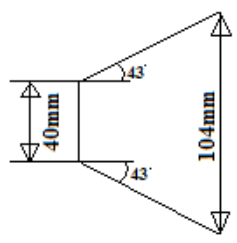

(d) Cone angle

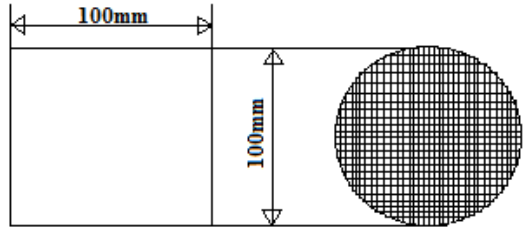

(e) Cylindrical honeycomb substrate

Figure 4. Parts of catalytic converter.

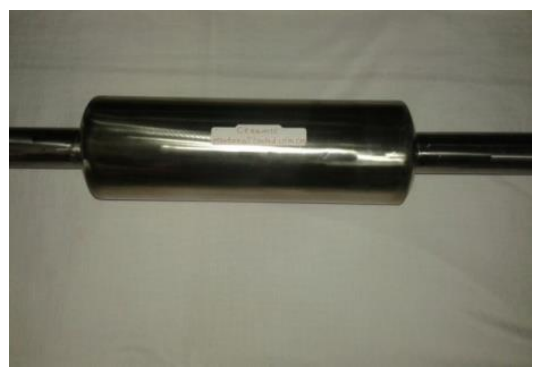

Figure 5. Assembled catalytic converter.

\section{EXPERIMENTATION DETAILS}

Exhaust emission tests were carried out on a three-cylinder, the MPFI petrol engine which is coupled with an electrical dynamometer. Table 4 shows the engine specifications. Five gases analyzer (Indus make PEA 205 model) is connected to the tail pipe of the engine to measure $\mathrm{CO}, \mathrm{CO}_{2}, \mathrm{HC}$, and $\mathrm{O}_{2}$. A probe is mounted at the exhaust pipe which supplies exhaust gasses samples to the gas analyzer. The amount of $\mathrm{CO}, \mathrm{CO}_{2}, \mathrm{HC}$, and $\mathrm{O}_{2}$ present in the exhaust can be read at the indicator panel of the exhaust gas analyzer. Engine tests were conducted by varying the loads $(0,2,4,6,8,10 \mathrm{~kg})$ and keeping the speed constant (2000RPM). In this work, the speed of the engine is kept constant because the load has a greater effect on the performance and emissions characteristics of the SI engine. By keeping the speed constant, it is possible to study the effect of brake power, air-fuel ratio, and torque on the performance and emissions characteristics of the SI engine. Figure 6 shows the experimental setup used in this work. In the first stage, exhaust emission test was conducted by fitting a $100 \mathrm{~mm}$ diameter catalyst $\left(\mathrm{CeO}_{2}\right)$ coated catalytic converter to the tail pipe of the test engine. In the second stage, exhaust emission test was conducted by fitting a $100 \mathrm{~mm}$ diameter non-catalyst coated (without $\mathrm{CeO}_{2}$ coating) catalytic 
converter to the tail pipe of the test engine. In the third stage, cold start exhaust emission test was conducted by fitting a $100 \mathrm{~mm}$ diameter catalyst coated $\left(\mathrm{CeO}_{2}\right.$ coating $)$ catalytic converter with a glow plug in the tail pipe of the test engine. In the last stage, exhaust emission test was conducted by fitting a $100 \mathrm{~mm}$ diameter catalyst coated $\left(\mathrm{CeO}_{2}\right.$ coating $)$ catalytic converter to the tail pipe of the test engine by supplying secondary air. The results obtained in these tests have been compared to the exhaust emissions of the engine without a catalytic converter.

Table 4. Engine specifications.

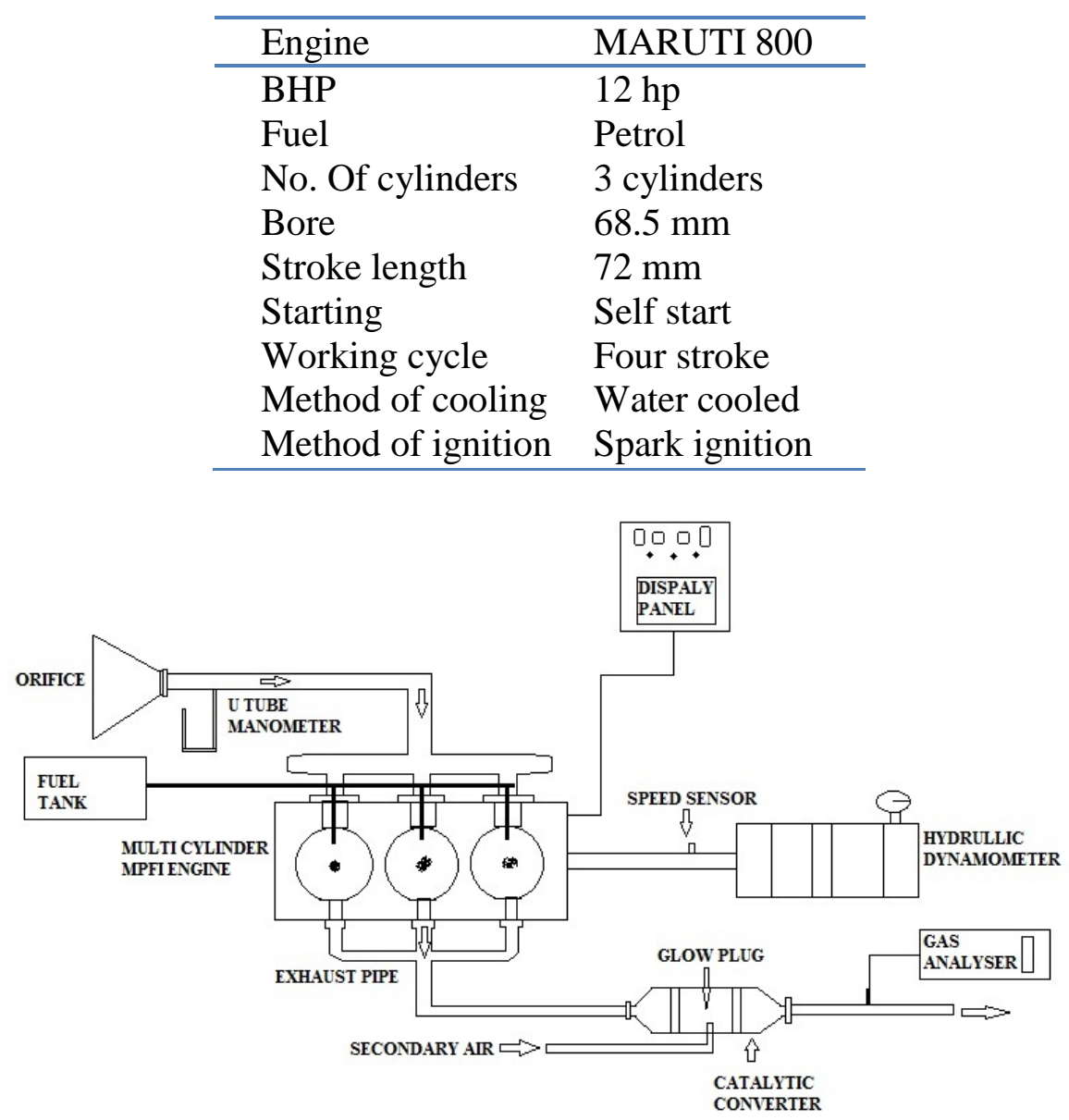

(a)

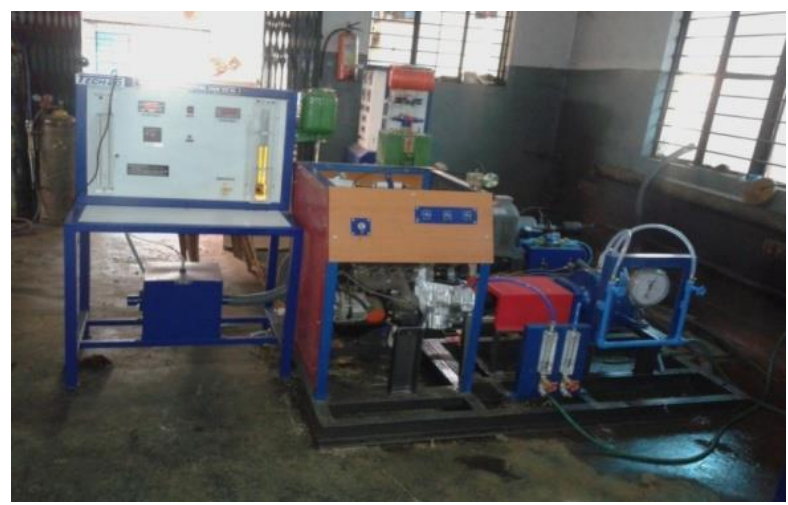

(b)

Figure 6. Schematic diagram and real experimental engine setup. 


\section{RESULTS AND DISCUSSION}

\section{Variation of CO Emission}

Figure 7 shows the $\mathrm{CO}$ emission at different loads. As the load on the engine is increasing, the $\mathrm{CO}$ emission is also increasing. The $\mathrm{CO}$ emission has increased from idling to full load when the catalytic converter is not used. The same trend was observed for all other test conditions. When the coated catalytic converter is fitted to the tail pipe, $\mathrm{CO}$ emission was reduced by $58 \%$ at full load in comparison with $\mathrm{CO}$ emission when the catalytic converter is not used because the catalyst coated on the honeycomb substrate oxidizes $\mathrm{CO}$ to $\mathrm{CO}_{2}$. In addition to this, at higher engine load, conversion of $\mathrm{CO}$ to $\mathrm{CO}_{2}$ is more because of higher exhaust gas temperature, which increases the catalytic activity of the catalyst [1]. There is an appreciable reduction in $\mathrm{CO}$ emission in the lower load range when glow plug is operated. The results indicate that $\mathrm{CO}$ emission has decreased to a value of $72 \%$ from $75 \%$ when the glow plug is heated up in the load range of $4 \mathrm{~kg}$. This is because the glow plug keeps the converter hot when exhaust gas temperatures are low. A reduction of $50 \% \mathrm{CO}$ emission was observed when a non-coated catalytic converter is used compared to a non-catalytic converter engine at full load operation because the honeycomb substrate material has $\mathrm{SiO}_{2}, \mathrm{Al}_{2} \mathrm{O}_{3}$, and $\mathrm{MgO}$ which act as catalysts and boost oxidation of $\mathrm{CO}$ to $\mathrm{CO}_{2}$. It was also observed that $\mathrm{CO}$ emission has increased $19 \%$ when the non-coated catalytic converter is used compared to the coated catalytic converter engine at full load operation due to the use of $\mathrm{CeO}_{2}$ as a catalyst.

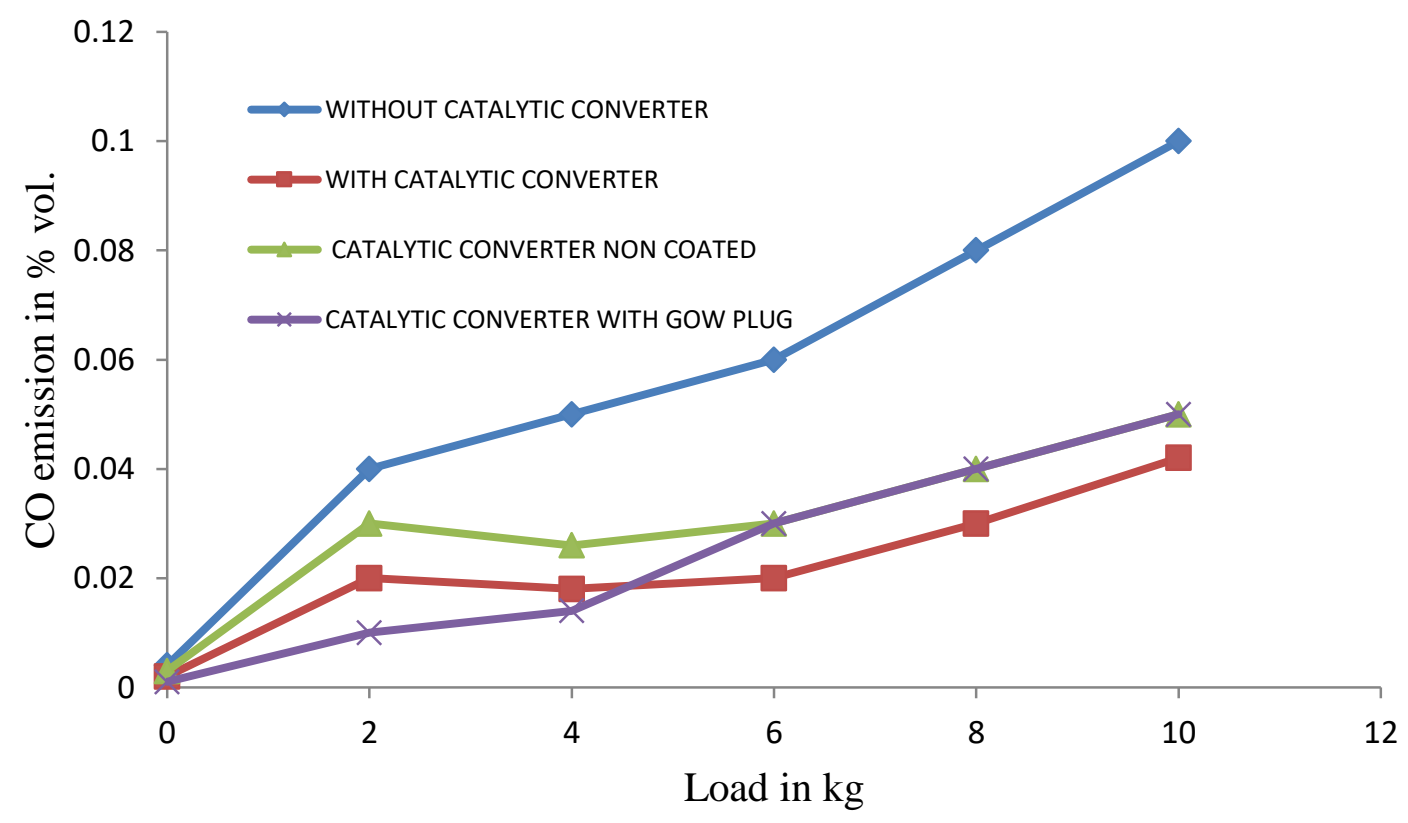

Figure 7. Effect of load on CO emission at different operating conditions.

\section{Variation of HC Emission}

Figure 8 shows the HC emission at different loads. It is clear from Figure 8 that HC emission (in ppm) increases with the increase in load for all test conditions. It was observed that $\mathrm{HC}$ emission has decreased $55.56 \%$ at the idling test condition and $69.23 \%$ at full load test condition when the $\mathrm{CeO}_{2}$ coated catalytic converter is used as compared to non-catalytic converter engine operation because the catalyst coated on the honeycomb substrate oxidizes un-burnt hydrocarbons to water vapor and oxygen. In addition to this, 
at higher engine load, conversion of un-burnt hydrocarbons to water vapor and $\mathrm{CO}_{2}$ is more because of higher exhaust gas temperature, which increases the catalytic activity of the catalyst [1]. The results indicate that the $\mathrm{HC}$ emission has decreased to a value of $55.6 \%$ to $81.6 \%$ when the glow plug is heated up in the load range of $0 \mathrm{~kg}$ to $4 \mathrm{~kg}$. A reduction of $36.21 \% \mathrm{HC}$ emission was observed when a non-coated catalytic converter is used compared to a non-catalytic converter engine at full load operation because the honeycomb substrate material has $\mathrm{SiO}_{2}, \mathrm{Al}_{2} \mathrm{O}_{3}$, and $\mathrm{MgO}$ which act as catalysts and boost oxidation of $\mathrm{CO}$ to $\mathrm{CO}_{2}$. It was also observed that $\mathrm{HC}$ emission has become 2.25 times when the non-coated catalytic converter is used compared to the coated catalytic converter engine at full load operation due to use of $\mathrm{CeO}_{2}$ as a catalyst [1]. Thus, there is a steady decrease in $\mathrm{HC}$ value with the introduction of the coated catalytic converter.

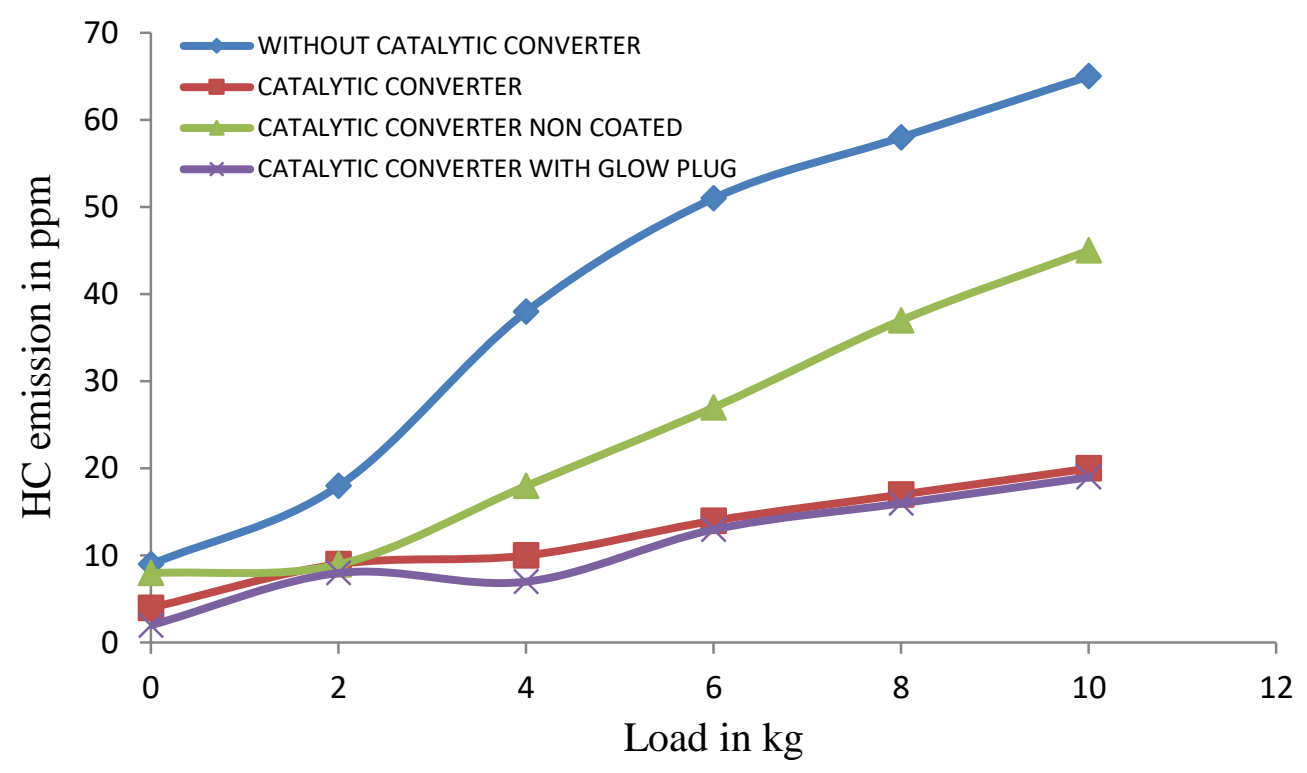

Figure 8. Effect of load on HC emission at different operating conditions.

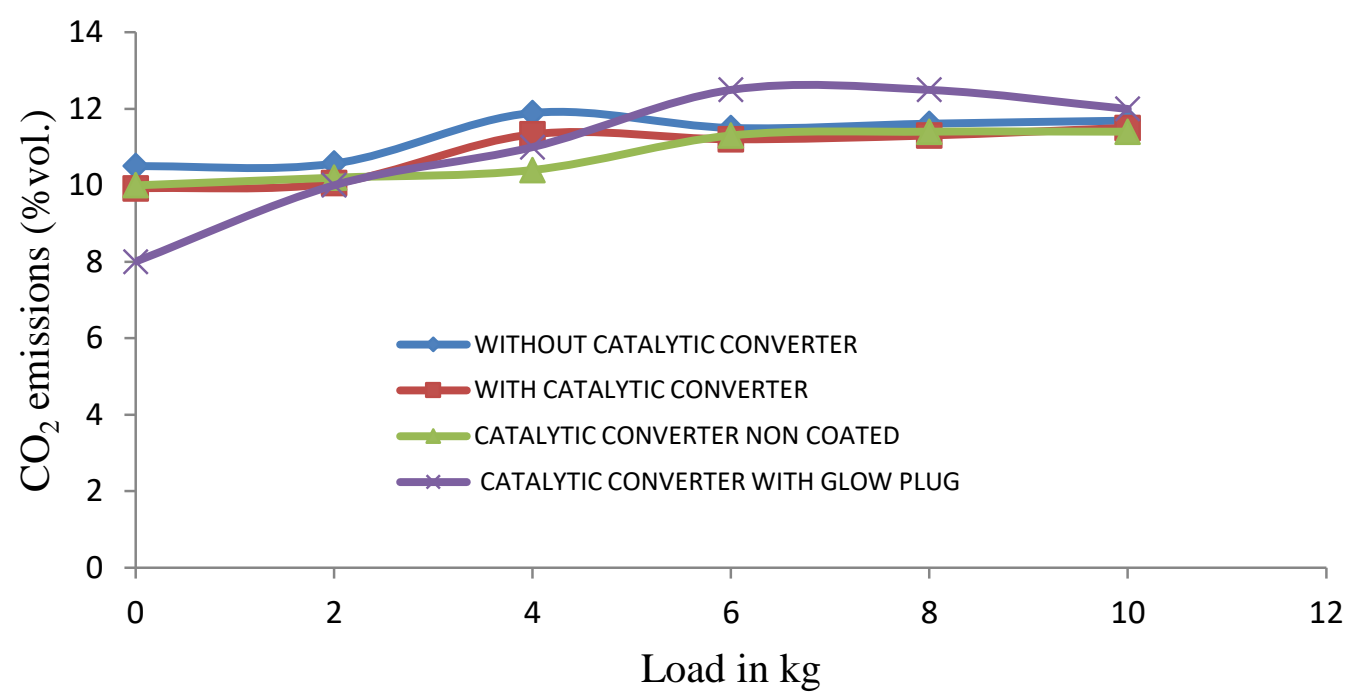

Figure 9: Effect of load on $\mathrm{CO}_{2}$ emission at different operating conditions. 
Figure 9 shows the $\mathrm{CO}_{2}$ emission at different loads. It was observed that $\mathrm{CO}_{2}$ emission increases with the increase in load for all test conditions. It was observed that $\mathrm{CO}_{2}$ emission has decreased $5.52 \%$ at idling test condition and $1.63 \%$ at full load test condition when the $\mathrm{CeO}_{2}$ coated catalytic converter is used compared to a non-catalytic converter engine operation because catalyst $\left(\mathrm{CeO}_{2}\right)$ oxidizes $\mathrm{CO}$ to $\mathrm{CO}_{2}$. The results indicate that $\mathrm{CO}_{2}$ emission has decreased to a value of $5.39 \%$ from $23.81 \%$ when the glow plug is heated up in the load range of $0 \mathrm{~kg}$ to $4 \mathrm{~kg}$. A reduction of $2.48 \% \mathrm{CO}_{2}$ emission was observed when a non-coated catalytic converter is used compared to a non-catalytic converter engine at full load operation because the honeycomb substrate material has $\mathrm{SiO}_{2}, \mathrm{Al}_{2} \mathrm{O}_{3}$, and $\mathrm{MgO}$ which act as catalysts and boost oxidation of $\mathrm{CO}$ to $\mathrm{CO}_{2}$.

\section{CONCLUSIONs}

It can be concluded that the $\mathrm{CO}, \mathrm{HC}$, and $\mathrm{CO}_{2}$ emissions can be reduced by using $\mathrm{CeO}_{2}$ coated catalytic converter at all engine load operations. It can also be concluded that cold start emissions can be controlled using a glow plug along with the $\mathrm{CeO}_{2}$ coated catalytic converter. The catalytic converter made of the non-noble $\left(\mathrm{CeO}_{2}\right)$ material has significant advantages such as inexpensive than the catalytic converter based on the noble material and a lower operating temperature than the noble metal and also the easy availability of the non-noble material. The non-noble material catalytic converter is the best option for reducing pollution when noble materials are not available.

\section{ACKNOWLEDGEMENTS}

The authors gratefully thank Nanjing Depurate Catalyst Co., Ltd, Nanjing, China for supplying both non-coated and $\mathrm{CeO}_{2}$ (catalyst) coated type ceramic honeycomb substrates. The author would like to be obliged to Tech-Ed Equipment Company Pvt. Ltd, Bangalore (India) for providing laboratory facilities to carry the exhaust gas analysis. The authors also acknowledge the support rendered by the staff of Department of Thermal Power Engineering, Visvesvaraya Technological University, Post Graduation Center, Mysore.

\section{REFERENCES}

[1] Heywood JB. Internal combustion engine fundamentals: Mcgraw-hill New York; 1988.

[2] Hasan MM, Rahman MM. Homogeneous charge compression ignition combustion: Advantages over compression ignition combustion, challenges and solutions. Renewable and Sustainable Energy Reviews. 2016;57:282-91.

[3] Yasin MHM, Mamat R, Aziz A, Yusop AF, Ali MH. Investigation on combustion parameters of palm biodiesel operating with a diesel engine. Journal of Mechanical Engineering and Sciences. 2015;9:1714-26.

[4] Mathur M, Sharma R. Internal combustion engines: Dhanpat Rai Publ.; 2005.

[5] Ganesan V. Internal combustion engines: McGraw Hill Education (India) Pvt Ltd; 2012.

[6] Sher E. Handbook of air pollution from internal combustion engines: pollutant formation and control: Academic Press; 1998. 
[7] Muharam Y, Mahendra M, Gayatri D, Kartohardjono S. Simulation of ignition delay time of compressed natural gas combustion. International Journal of Automotive and Mechanical Engineering. 2015;12:3125-40.

[8] Noor MM, Wandel AP, Yusaf T. The simulation of biogas combustion in a mild burner. Journal of Mechanical Engineering and Sciences. 2014;6:995-1013.

[9] Noor MM, Wandel AP, Yusaf T. Effect of air-fuel ratio on temperature distribution and pollutants for biogas MILD combustion. International Journal of Automotive and Mechanical Engineering. 2014;10:1980-92.

[10] Kumaran P, Gopinathan M, Kantharrajan S. Combustion Characteristics of Improved Biodiesel in Diffusion Burner. International Journal of Automotive and Mechanical Engineering. 2014;10:2112-21.

[11] Hamada KI, Rahman MM, Abdullah MA, Bakar RA, A. Aziz AR. Effect of mixture strength and injection timing on combustion characteristics of a direct injection hydrogen-fueled engine. International Journal of Hydrogen Energy. 2013;38:3793-801.

[12] Jaichandar S, Annamalai K. Jatropha oil methyl ester as diesel engine fuel - an experimental investigation. International Journal of Automotive and Mechanical Engineering. 2016;13:3248-61.

[13] Pundir B. Engine emissions: pollutant formation and advances in control technology: Alpha Science International, Limited; 2007.

[14] Kisku G. Nature and Type of Pollution from Automobiles and Strategies for its Control. Industrial Toxicology Research Centre, Environmental Monitoring Division, Lucknow. 2013:1-16.

[15] Ye S. Oxidation Catalyst Studies on a Diesel Engine: University of Bath; 2010.

[16] Crypton. Understanding CAT - Catalytic Converters. 2012.

[17] Kašpar J, Fornasiero P, Hickey N. Automotive catalytic converters: current status and some perspectives. Catalysis Today. 2003;77:419-49.

[18] Wei J. Catalysis for motor vehicle emissions. Advances in Catalysis. 1975;24:57129.

[19] Shinjoh H. Rare earth metals for automotive exhaust catalysts. Journal of Alloys and Compounds. 2006;408:1061-4.

[20] Amin C, Rathod PP, Student P. Catalytic converter based on non-noble material. International Journal of Advanced Engineering Research and Studies; 2012.

[21] Walke P, Deshpande N, Mahalle A. Emission characteristics of a compression ignition engine using different catalyst. Proceedings of the World Congress on Engineering: Citeseer; 2008.

[22] Gaikward D, Dange H. Experimental investigation of four stroke SI engine using oxyrich air energizer for improving its performance. International Journal of Technology Enhancements and Emerging Engineering Research,. 2014;2:104-9.

[23] Gaines L, Rask E, Keller G. Which Is Greener: Idle, or Stop and Restart? Comparing Fuel Use and Emissions for Short Passenger-Car Stops. Transportation Research Board of the National Academies. 2012.

[24] Burch SD, Keyser MA, Potter TF, Benson DK. Thermal analysis and testing of a vacuum insulated catalytic converter. SAE Technical Paper; 1994.

[25] Veeraragavan V. Fabrication and testing of a catalytic convertor. International Journal of Application or Innovation in Engineering \& Management. 2013;2:3504.

[26] Karuppusamy P, Senthil DR. Design, Analysis Of Flowcharacteristics Of Catalytic Converterandeffects Of Backpressure On Engine Performance. 
Development and characterization of cerium oxide catalyst supported on ceramic honeycomb substrate to reduce emissions of spark ignition engine

International journal of Research in Engineering and Advanced technology. 2013;1.

[27] Bhaskar K, Nagarajan G, Sampath S. Experimental investigation on cold start emissions using electrically heated catalyst in a spark ignition engine. International Journal of Automotive and Mechanical Engineering. 2010;2:105-18.

\section{NOMENCLATURES}

$\mathrm{CO} \quad-\quad$ Carbon Monoxide

$\mathrm{CC}-$ Catalytic Converter

$\mathrm{HC} \quad-\quad$ Hydrocarbon

$\mathrm{SiO}_{2}-$ Silica

$\mathrm{MgO}$ - Magnesia

$\mathrm{Al}_{2} \mathrm{O}_{3}$ - Aluminum oxide

$\mathrm{La}_{2} \mathrm{O}_{3}$ - Lanthanum oxide

$\mathrm{Na}_{2} \mathrm{O}$ - Sodium oxide

$\mathrm{Fe}_{2} \mathrm{O}_{3}-\quad$ Ferric oxide

$\mathrm{SO}_{4}^{-2}-\quad$ Sulfate 